\title{
Knowledge on Practice Management and Financial Literacy: Need of the Hour
}

\author{
Subash C Parija ${ }^{1}$, Manivasakan Shivasakthy ${ }^{2}$ \\ Journal of Scientific Dentistry (2019): 10.5005/jp-journals-10083-0919
}

Health profession education courses concentrate on developing the knowledge, skills, and attitude of the graduates to become skilled health professionals. There were more job opportunities in the academic sector in dentistry earlier. With the increase in the number of dental colleges and dentist population ratio in urban sector compared with that of rural sector, the survival of the dentists has become a challenge. The graduates should have knowledge on practice management and financial management to become successful entrepreneurs and also to succeed in their life. This area is often left unfocussed in our curriculum.

Unfortunately, the education system in India does not focus on financial literacy of the students even in higher education. The traditional parenting culture that prevails here keep the children in a dependent mode for longer years when compared with that of the Western countries. The students lack awareness on the real world financial problems and options. The lack of financial literacy further complicates the already existing employment issues.

A study done on the readiness of the Indian dental students to practice after graduation has revealed that an $88 \%$ of the respondents perceived lack of training in practice management. ${ }^{1,2}$ The American Dental Education Association conducted a survey in 2015 and had found that one of the top unprepared areas for practice after graduation was practice administration as reported by the students. ${ }^{3}$ Alumni of US dental school have revealed in a study that they had gained most of their practice management knowledge and skills after graduation. ${ }^{4}$

An exploratory study on impact analysis was done to investigate the students' entrepreneurial self-efficacy (ESE), following a dental school's practice management education in the United States for the first time in dental education. ${ }^{5}$ The results of the study revealed a greater impact on the final year students' ESE following the implementation of practice management courses in the curriculum.

Fundamental knowledge on financial skills for budgeting, understanding invoice of the bills, comparing quotations before purchase, and analyzing cost-benefit ratio is mandatory in any work setup. The graduates should be able to know the difference between "want" and "need" to set up a quality healthcare practice. Financial literacy allows the individuals to assess the implications of

${ }^{1}$ Sri Balaji Vidyapeeth (a Deemed University), Pillayarkuppam, Puducherry, India

${ }^{2}$ Department of Prosthodontics, Crown and Bridge, Indira Gandhi Institute of Dental Sciences, Sri Balaji Vidyapeeth, Pillayarkuppam, Puducherry, India

Corresponding Author: Manivasakan Shivasakthy, Department of Prosthodontics, Crown and Bridge, Indira Gandhi Institute of Dental Sciences, Sri Balaji Vidyapeeth, Pillayarkuppam, Puducherry, India, Phone: +91 9940724320, e-mail: shivasakthym@igids.ac.in

How to cite this article: Parija SC, Shivasakthy M. Knowledge on Practice Management and Financial Literacy: Need of the Hour. J Sci Dent 2019;9(1):1.

Source of support: Nil

Conflict of interest: None

the financial options and facilitates the decision-making process. Curricular reform to integrate practice management and financial literacy in Indian Dental Education is the need of the hour and needs to be emphasized by the dental academicians to the statutory bodies.

\section{References}

1. Lagali-Jirge V, Umarani M. Evaluation of readiness to practice among interns at an Indian dental school. J Contemp Med Educ 2014;2: 227-231. DOI: 10.5455/jcme.20141105071940.

2. Lagali-Jirge V. Need for paradigm shift in indian dental education: a case for change toward competency-based education. J Indian Acad Oral Med Radiol 2015;27(2):230-236. DOI: 10.4103/0972-1363.170143.

3. Wanchek T, Cook BJ, Anderson EL, Valachovic RW. Annual ADEA survey of dental school seniors: 2015 graduating class. J Dent Educ 2016;80(5):612-629.

4. Barber M, Wiesen R, Arnold S, Taichman RS, Taichman LS. Perceptions of business skill development by graduates of the university of Michigan dental school. J Dent Educ 2011;75(4):505-517.

5. Mollica AG, Cain K, Callan RS. Using assessments of dental students' entrepreneurial self-efficacy to aid practice management education. J Dent Educ 2017;81(6):726-731. DOI: 10.21815/JDE.016.036.

(c) The Author(s). 2019 Open Access This article is distributed under the terms of the Creative Commons Attribution 4.0 International License (https://creativecommons. org/licenses/by-nc/4.0/), which permits unrestricted use, distribution, and non-commercial reproduction in any medium, provided you give appropriate credit to the original author(s) and the source, provide a link to the Creative Commons license, and indicate if changes were made. The Creative Commons Public Domain Dedication waiver (http://creativecommons.org/publicdomain/zero/1.0/) applies to the data made available in this article, unless otherwise stated. 